\title{
Interactive E-book in Local Potention-Integrated Natural Science Contextual Teaching \& Learning During COVID-19 Distruption to Recovery: A Content Analysis
}

Rika Nuryani Suwarno ${ }^{1, *}$ Zuhdan Kun Prasetyo ${ }^{2,}$ Yustar Afif Priambodo ${ }^{1,}$ Khoirul Huda ${ }^{1}$ Hindun Hidayatun Nai'mah ${ }^{3}$

\author{
${ }^{1}$ Master of Natural Science Education, Faculty of Mathematics and Natural Sciences, Universitas negeri \\ Yogyakarta, Indonesia \\ ${ }^{2}$ Department of Natural Science Education, Faculty of Mathematics and Natural Sciences, Universitas negeri \\ Yogyakarta, Indonesia \\ ${ }^{3}$ Batam 40 Junior High School, Kepualuan Riau, Indonesia \\ *Corresponding author. Email: rikanuryani.2019@student.uny.ac.id
}

\begin{abstract}
Some competencies of students for $21^{\text {th }}$ century era required such as critical thinking, scientific culture, and making best decision for problems solving on their daily life. Students's competencies in Indonesia still low and need to improved. Now because of the pandemic period, students are limited to do learning activities which ultimately forces students to study from home with social distancing. Teachers have tried many ways to improve it during highly contagious corona virus disease since December 2019. Therefore, an alternative solution can be used is an interactive e-book as learning resources. This qualitative research aims to give interactive e-book local potention-integrated overview on how it can motivate students to deeply learn science and more contextual by content analysis. E-book requires 6 contents good packaging to help students easier to study for improving their ability: picture, animation videos, hyperlink, interactive question, student worksheet, and assessment (evaluations) which Piayu Laut-integrated. E-book Piayu Laut-integrated should make students interactive between teacher, other students and other learning resources for interactive and contextual teaching and learning for this covid-19 distruption to recovery fase. It requires match between the local potential and associated learning topic with student worksheet and questions.
\end{abstract}

Keywords: Interactive e-book, Local potention, Covid-19 distruption to recovery era

\section{INTRODUCTION}

Education world continues growing-up on going to $21^{\text {th }}$ century era. It forces people including students to have some competencies. However, they require competencies on critical thinking, scientific culture, and making correct decision for problems solving on their daily life [1]. Students also required to have competencies by UNESCO to know, to do, to be, and to live together [2]. On the other hand, unpredictable pandemy happened. Corona virus 2019 (COVID-19) continues spreading in many countries in the world since December 2019. It has impacts on aspects in our life including on learning. The major impact of that is how to keep learning in the distruption. It is a big challenge to the goverment and its education community [3]. Most governments made rules to temporarily close educational institutions in their efforts to spread the COVID-19 pandemic [4]. Their efforts have an impact on the more vulnerable and disadvantaged communities for the continuity of education for all through distance learning, one of which is in Indonesia. However, until now, Indonesia is still experiencing difficulties with this mitigation.

Indonesian students continued their education by online and had been encouraged social distancing to 
prevent further spread of the highly contagious disease since March 2020, especially in big cities [4], [5], [6]. Learning process when staying at home is more preferable, compel to have reflections and inovations. The quietest teachers about new technology are very involved and supportive. However, some students in this situation can be very stressful, confusion and sources of unease [7]. It happened because of the digital tecnologies have synonymous on social media, chat, new encounters, and relaxation. It changed from a handy distruption into arduous work then being serious problem on their concentration.

Some questions will be not solved yet. First, the corona virus-19 pandemic birth a real digital revolution and lead off a new era that is distance learning or normaly learning. Many students prefer restlessly returning to their benches of the auditoriums or comfortably stay at home by joining online courses? It is really being a big question. We will get the answers when our normal life return. However, good investment of humanity in the future is digital technology-an extraordinary competitive market to develop [7]. One of the digital technologies for the solution is interactive ebook [8], [9], [10], [11]. A good ebook can fulfill student competencies in such an era is an ebook integrated its neighbourhood environment that is Piayu Laut for Batam Island students. So that, this research aims to give interactive e-book local potention-integrated overview on how it can motivate students to deeply learn science and more contextual.

\section{METHODS}

This qualitative research is content analysis with more than 35 featured articles. Next part of this paper is organized into section 2 and section 3. Section 2 will present a deep analysis of interactive e-book in local potention-integrated natural science learning during educational covid-19 distruption to recovery. Then, it continued with section 3 by the conclusion of this work.

\section{ANALYSIS OF INTERACTIVE E- BOOK IN LOCAL POTENTION- INTEGRATED NATURAL SCIENCE LEARNING DURING EDUCATIONAL COVID-19 DISTRUPTION TO RECOVERY}

This section presents analysis of interactive ebook in Local potention-integrated natural science learning during educational Covid-19 distruption to recovery.

\subsection{Interactive E-book}

Electronic book (e-book) is one of learning media that can be used to help or support the student learning process [12]. According to Naomi Baron and collaborators, students actually use their free time to read books in digital format [13]. It is a digital form of a book that can attract students to learn which enjoyable experience for readers contains pictures, sounds, animations, and learning videos [14]. Meanwhile, interactive e-books are electronic books in interactive format containing information in the form of images or text [14]. E-books can be in the form of word, pdf, exe, html, txt, and others.

E-book needs creativity on combining the software. It specifically designed for subject matter or reading things through electronic media such as computers [15]. Such e-book development can use the MOBI application, aPUBee-Marker, Flip Book Pdf, Flash or the simple Sigil application, Callibre. Ebooks can be exposed via a computer electronically. In most case, it consists of paper set including text and images. In addition, it can also create them on digital form of informations in format plain text, enticing visualizations images, and content of multimedia that can be integrated into e-books. Ebooks deeply examined can be deciphered as a technology that utilizes computers to show off multimedia information in a brief and dynamic kind. The information provided is more properous than hard books. It also can improve students's competences. A research by Widodo showed that there was scientific literacy improvement by multimedia based on science literacy especially for $\mathrm{Z}$ generation [16].

Interactive e-books can be learning resources that have their own provisions that are used as guidelines, innovations and references in the world of education. In its development, e-books need to follow the following provisions: font size 12 and easy to read, the text chosen is justify, uses bold fonts for important information, the images used are clear, and provides information on each image [17]. National Ministry of Education in Indonesia stated that e-book should consist of evaluation components, namely: introduction, materials, student worksheets, quizzes, and a list of references [18]. Etymologically, interactive means that it has mutual influence and is mutually active. The concept of interactive word is closely relationed to computer-based media. In other hand, interactive here is an activity of interaction 
between media and the users [18]. Meanwhile, interactive learning defines 4 interactivity levels, namely: a) level 1: students act alone as information recipients; b) level 2: students make easy responses to hints; c) level 3: students make various responses applying various techniques in to response instructions; d) level 4: students are straight bounded in appropriate questions and responses as complex as life [18].

There was a next version e-books named interactive e-books in 2011 with some features: the interaction takes place in multi-channels; 20 interactions between users, digital books and the environment, interesting elements on it among themselves; 40 interactions occur together among many components [17]. There also was some features which can be added in: page turning, automatic search, hyperlinks (direct links), virtual location markers, annotations, bookmarks, multimedia, term search using an online encyclopedia, automatic indication of synonyms, and being able to automatically indexes the tip of it [19]. Interactive ebook on cartoon is a digital book in which the user, digital type, and environment can be relied each other on high level. Its elements can bring interactive communication between the environment and themselves as great as many communication channels and users concurrently [20].

\subsection{Piayu Laut as Local Potention in Batam Island}

Batam City is an island located between the waters of the Malacca Strait and Singapore. Batam included into an emerging transport hub, industrial boomtown, and part of a free trade zone [21]. Batam City area like other areas in the Riau Islands Province, is also part of the continental shelf. The islands scattered in this area are remnants of erosion or shrinkage of the protersier land that stretches from Peninsular Malaysia / Singapore in the north to Moro and Kundur and Karimun Islands in the south. Batam City area is part of the Sunda Shelf which stratigraphically is an area with potential for submarine plases deposition. Geographically, Batam City is located in shallow sea waters, with a coastal area, and lands area totals $415 \mathrm{~km}^{2}(41.500$ hectares $)$ [22]. Based on the interpretation of the seismic record, it is stated that the geological landscape structure found in the seabed waters of the Riau Islands is a fault. Batam Island is a large island out of 329 islands in Batam City [23]. Each area in Batam is unique, one of its uniqueness is Piayu Laut, Duriangkang.

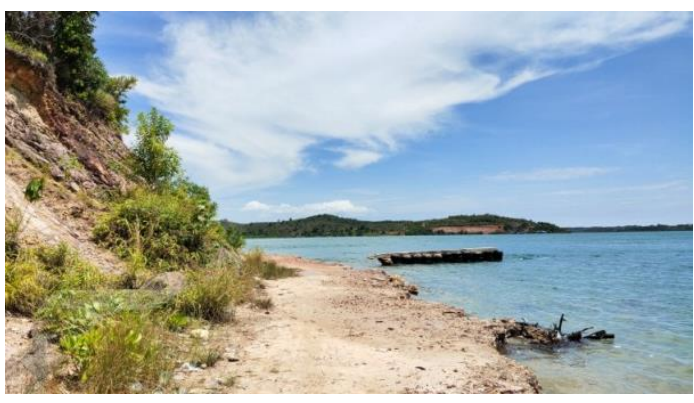

Figure 1 Piayu Laut

Kampung Tua Tanjung Piayu Laut is one of the Old Villages in Batam City which has a long historical record about the pathway for Sultan Sulaeman Ibnu Jawi Ibnu Sultan Abdul Rahman who disguised himself as an ordinary citizen [21]. It is located in Kelurahan Tanjung, Duriangkang, Batam City. It which is centered in Pancur and is part of Sungai Beduk District.

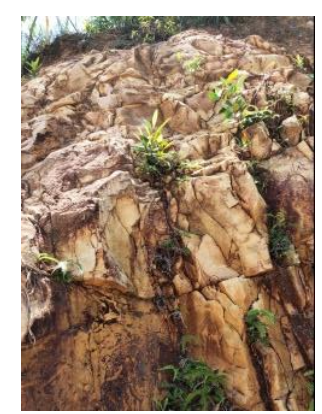

Figure 2 Rocks structure of Piayu Laut's Land

Geologically, Piayu Laut is unique because in one closed area it has the potential for the location of hills, beaches, to the sea which is very close, ranging from just a few meters with different land structures. It's soil and rock structure, which is known as red soil. This land most composed by alluvium (Qa) and the Duriangkang formation that like putri island [24]. Alluvium is a yellowish red sand formation. This structure is what makes the soil red. This type of rock has a high level of stability and is used for built areas in the agricultural, plantation, mangrove forest sectors. Meanwhile, the Duriangkang formation is a fertile and fairly stable gray-black shale.

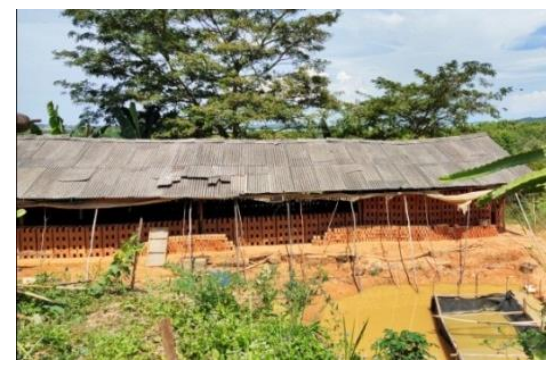

Figure 3 Land use for brick industrial centers 
Piayu Laut which is famous in culinary tourism is currently undergoing physical improvements for various sectors, especially tourism [21]. This repair process uses the hill soil material that is there. The management of the Piayu Laut requires environmental studies, not only economic studies, in terms of physical, biological, and chemical aspects that are usually carried out by a scientist. This becomes important for the continuity of life there.

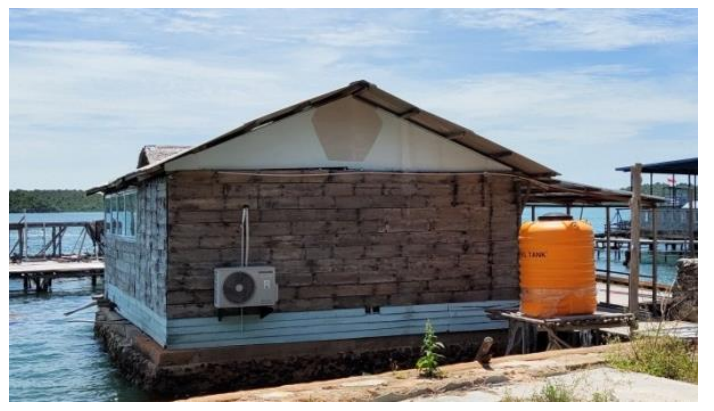

Figure 4 Utilization of land materials for the construction of the house tourism sector.

\section{$3.3 C T L$}

CTL (Contextual Teaching and Learning) is a conseption on teaching and learning which supports teachers link subject matter content to student's problems, and also motivates them forming knowledge integrations to its application for their daily lives [25],[19]. CTL uses to increase learners's motivation and adjust it, framing meaningful version on actions contexts and interactions within students's daily live [26]. They will not learn by memorizing but through their experiences. They are expected to construct knowledge instead of memorizing the concepts that have been found [27]. Some previous conducted studies proved by their results that students's learning outcome had influenced by learning through CTL models on the topic of colloids. The students's learning outcomes by the research showed higher skor for experiment class than control [28].

\subsection{Learning during Covid-19 distruption to recovery through interactive e-book}

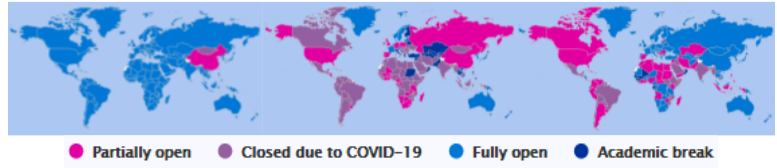

Figure 5 School distribution of closure in the world on Feb-Juny-October 2020
These nationwide closures by goverment are impacting hundreds of millions of students, teachers and also the their learning process [29]. Based on UNESCO data, school distribution of closures in countries can be looked above (Figure 5). From the figure above, we knew that reaching a new recovery fase after the distruption of that COVID-19 is real but it cannot be predicted when pandemy done is.

The goverment developed new learning modes have appeared that can open more opportunities for flexible learning, such as open learning. It aims to make learners more independent and self-determined, while teachers became facilitators on that learning. This model is better for reducing the risk of spreading the virus in the school environment which has an impact on safety for students. In the other hand, natural science requires contextual learning, with contextual teaching learning which is usually associated with local potentials near students. Now because of the pandemic period, students are limited to doing learning activities which ultimately forces students to study from home. And using technology that allows students to keep learning and still be interesting. Student competence which is the demand of the $21 \mathrm{st}$ century is increasingly becoming a problem because of this limitation. A special learning media is needed to be a solution to these problems.

From recently education undergoes a significant transformation along COVID-19 distruption with the emergence of digital technology, such as: internet conection, mobile phones, smartphones, laptops, and the most recent one wasthe so-called electronic book or e-book [30]. E-book is defined as the book available in electronic form through four different methods: downloadable e-book, online e-book reader; restricted e-book form; and that accessed via the web. Over time, the ebook has changed its definition in line with trends. Students who understand those emerging technologies think of themselves as more capable learners who those who do not understand the development of technologies such as e-book [30]. In other hand, curriculum that applies in Indonesia requires a learning process that allows students to be interactive between the teacher and their learning resources, especially learning environment. These learning resources can be used to create effective learning. The learning resource most commonly used by teachers in learning is books. Books still play a very important role as the main and supporting learning resource as well as the most effective learning resource. 


\subsection{Interactive e-book in Piayu Laut- integrated Natural Science Contextual Teaching \& Learning during Educational Covid-19 Disruption to Recovery}

We already discussed that learning science is closely related to daily experiences. It is connected to the four elements of nature science there are: (1) attitude; (2) process; (3) products; (4) application [31]. We also have enriched this environment with various activities and daily life [26]. Its purpose is to respond to the demands of students' competencies in equal difficulties. Ebooks that are integrated with local potential with all the multimedia content in them can increase students' motivation and abilities in the 21 st century, especially critical thinking skills, as long as the content in the book is interactive media and makes students think critically as well.

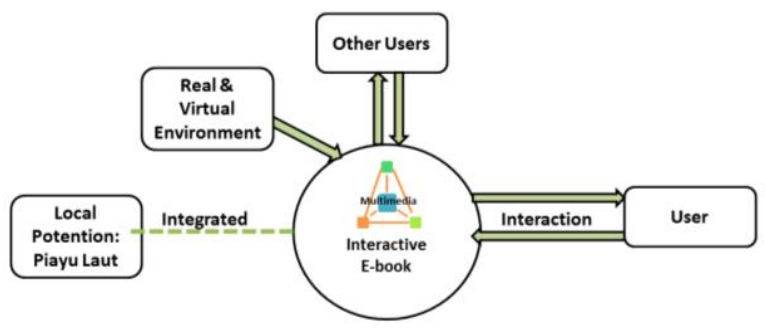

Figure 6 Interaction in interactive e-book Piayu Laut-integrated.

According to adaptation figure by Firdausy [18], there are four type of interaction which happened in the e-book of Piayu Laut-integrated: 1) among multimedia/digital in the book elements; 2) between environments; 3) between user and the digital book; 4) between other users/online communities. This interactive ebook can contain various kinds of text, images and a combination of various forms of motion animation that allow students to relate them to memories and things that are contextually present in them. The content in Piayu Laut can be integrated through text, images, video, or others. Thus, some contents needed in the interactive e-book Piayu Lautintegrated can be readed on the table below.

Table 1. Content needed in the interactive e-book Piayu Laut-integrated

\begin{tabular}{|l|l|}
\hline Content & Description of Integration \\
\hline Pictures & Many kind of pictures can help \\
such as & student to learn the topic when they \\
table, & can't do observations on that time. It \\
graphic, & also gain students's motivation. It \\
animation, & makes student interested on \\
\hline
\end{tabular}

\begin{tabular}{|c|c|}
\hline etc. & science learning. \\
\hline Video & $\begin{array}{l}\text { Student can explore the topic deeply } \\
\text { by interaction that shown in video. It } \\
\text { allows student have interactive } \\
\text { session. The content of video } \\
\text { increase students's understanding } \\
\text { the topic easily. Thus, video needed } \\
\text { bases on case can assist student to } \\
\text { conceive the problem in Piayu Laut. }\end{array}$ \\
\hline Hyperlink & $\begin{array}{l}\text { Hyperlink allows students to directly } \\
\text { roam the article or media about } \\
\text { social issues outside the book. This } \\
\text { metode uses for improving } \\
\text { students's problems solving } \\
\text { scientifically. }\end{array}$ \\
\hline $\begin{array}{l}\text { Interactive } \\
\text { question }\end{array}$ & $\begin{array}{l}\text { Interractive question given bases on } \\
\text { indicators of students's competence. } \\
\text { It usually set after the picture, } \\
\text { hyperlink or video. }\end{array}$ \\
\hline $\begin{array}{l}\text { Students's } \\
\text { worksheet }\end{array}$ & $\begin{array}{l}\text { Students's worksheet can assist } \\
\text { students to gain competences in } \\
\text { each aspects. It also can train } \\
\text { students's good attitude. }\end{array}$ \\
\hline Evaluation & $\begin{array}{l}\text { Here is some questions as } \\
\text { evaluation by test items based on } \\
\text { indicators of the competence. }\end{array}$ \\
\hline
\end{tabular}

Natural Science related to the environment especially neighbourhood environment. Various phenomena, activities or condition in the neighbourhood environment can be used for learning resources. Some local potentials in the society have been scientifically tested to be used as Natural Science teaching resources [32]. The local potentials used in the learning activities are needed, for example on the development of learning instrument [33],[34], including local potential of Piayu Laut, Batam Island. Student's closer environment made them easier to understand then can solve some problems [35]. It means that local potentials in the student's neighbourhood environment support them to comprehend learning instrument which are delivered.

Current learning in certain materials rarely relates it to local potential, one of which is science learning 
in Batam, even though Batam has a very interesting local potential to be studied through science learning. Piayu Laut is one of the epic potentials that allows it to be integrated in science learning. It's because in one closed area it has the potential for the location of hills, beaches, to the sea which is very close, ranging from just a few meters with different land structures. The large diversity of human activities and members of its ecosystem, both plant animals and others, can be found in Piayu Laut and can be further explored for scientific learning. In addition to good packaging for the ebook, it requires a match between the local potential and the associated learning topic.

In normal conditions, core competencies and basic competencies are adjusted to the 2013 revised curriculum in Permendikbud Number 37 of 2018. Some schools around continue to use these rules even though in abnormal circumstances such as the Covid19 pandemic. Some schools can follow the latest rules of learning under special conditions based on the Decree of the Head of the Research and Development and Bookkeeping Agency number 018 / H / KR / 2020 in August 2020 regarding core competencies and basic bompetencies at all levels of education for abnormal conditions. This really depends on the policies of each school. However, Piayu Laut can still be integrated in the following topics: risk reduction measures before, during, and after a disaster according to the threat of disaster in the area; the concept of energy, various sources of energy, changes in the form of energy in everyday life, including photosynthesis; interactions of living things between their environment as well as population dynamics because of these interactions; the pollution of environmental and its impacts on the ecosystem; relating the physical and chemical properties of soil, living organisms in soil, with the importance of soil for the sustainability of life; and environmentally friendly technology products and processes for sustainability of life.

After observing and studying and discussing the teacher there, Piayu Laut which are unique in soil structure, geology, and physical potential can be closest related to the topic of Soil and Sustainability. This topic is contained in the Basic Competencies of Junior High Schools in Indonesia in grade nine. We found a variety of content that could be linked in science learning on the topic of land and survival. The details can be visible in the table below.
Table 2. Integration piayu laut as science learning resource for land and sustainability topic

\begin{tabular}{|l|l|}
\hline Content & Description of Integration \\
\hline $\begin{array}{l}\text { Land for Life } \\
\text { The Role of } \\
\text { Soil } \\
\text { Organisms }\end{array}$ & $\begin{array}{l}\text { The role of the land of Piayu } \\
\text { Duriangkang }\end{array}$ \\
\hline $\begin{array}{l}\text { Soil } \\
\text { the Piayu Laut ecosystem }\end{array}$ \\
\hline $\begin{array}{l}\text { Formation } \\
\text { Components }\end{array}$ & $\begin{array}{l}\text { The formation and horizon of } \\
\text { the land, especially the red } \\
\text { land in Piayu Laut }\end{array}$ \\
\hline $\begin{array}{l}\text { Soil fertility } \\
\text { rate and its } \\
\text { influencing } \\
\text { factors }\end{array}$ & $\begin{array}{l}\text { Soil components in Piayu Laut } \\
\text { to mining and landslides in the } \\
\text { Piayu Laut area }\end{array}$ \\
\hline
\end{tabular}

A good e-book to fulfill student competencies in such an era is an e-book that is integrated with its local potential. Seven main components of CTL can be used in the preparation of the ebook, namely [19]: 1) Building students' own knowledge (contructivism); 2) inquiry; 3) questioning; 4) Learning community; 5) Modeling; 6) Reflect at the end of each lesson (reflection); 7) Perform authentic assessment. Inquiry activities train students to identify, analyze and evaluate a problem [36]. Therefore, interactive ebook Piayu Laut-integrated can trains students to deeply learn science and contextually then improved students's competencies for this covid-19 distruption to recovery fase.

\section{CONCLUSION}

Interactive e-book in Piayu Laut-integrated natural science contextual teaching \& learning can use during educational covid-19 distruption to recovery. Interactive e-book's content can assist teacher to improve student's motivation, deeply of learning matter, and their attitude. Interactive e-book Piayu Laut-integrated bring student meaningful learning experience. The students can study by themself and improve students's competences. 


\section{REFERENCES}

[1] I. Turan, Y. Fildan, C. Yildıran, Critical Thinking as a Qualified Decision Making Tool, Journal of History Culture and Art Research 8(4) (2019) 1-18. DOI: https://doi.org/10.7596/taksad.v8i4.2316

[2] C. Scott, The Futures of Learning 2: What Kind of Learning for the 21st Century?, unesdoc.unesco.org, Nov. 2015. Accessed on: Oct 2020. [Online]. Available: https://pdfs.semanticscholar.org/fdf6/502f635dc 8408dcc4f9c6122b4398b2a758c.pdf.

[3] R.H. Huang, D.J. Liu, A. Tlili, J.F. Yang, H.H. Wang, Handbook on Facilitating Flexible Learning During Educational Disruption: The Chinese Experience in Maintaining Undisrupted Learning in COVID-19 Outbreak, Smart Learning Institute of Beijing Normal University, 2020.

[4] I.N. Sutarsa, A. Prabandari, F. Itriyati. Commentary: COVID-19 Self-Isolation is Punishing The Poor in Indonesia. Channel News Asia, Channel News Asia, Mar 2020. Accessed on: Oct. 2020. [Online]. Available: https://www.channelnewsasia.com/news/comme ntary/COVID-19-coronavirus-indonesiapoorgig-work-gojek-self-isolate-12567552.

[5] I. Expat, Indonesia and COVID-19, Indonesia Expat, Mar 2020. Accessed on: Oct. 2020 [Online].

Available: https://indonesiaexpat.biz/featured/COVID-19and-indonesia/

[6] N.S. Times, Indonesia Mulls LockdownCOVID-19 Death Toll Hits 114, New Straits Time, Mar. 2020. Accessed on: Oct. 2020. [Online].

Available: https://www.nst.com.my/world/world/2020/03/5 79298/indonesia-mulls-lockdown-COVID-19death-toll-hits-114

[7] Y. Bentata, COVID 2019 Pandemic: A True Digital Revolution and Birth of A New Educational Era, or An Ephemeral Phenomenon?, Medical Education Online 25(1) 2020-2021.

DOI: https://doi.org/10.1080/10872981.2020.1781378

[8] M. Takev, E. Somova, M.R. Artacho, M. Castro, Can e-book technology be enough to support elearning?, in: IEEE Global Engineering Education Conference, vol. 2020,
Porto, Portugal, 2020, pp. 1915-1921. DOI: https://doi.org/10.1109/EDUCON45650.2020.9 $\underline{125342}$

[9] D.D. Prasetya, A.P. Wibawa, T. Hirashima, Y. Hayashi, Designing Rich Interactive Content for Blended Learning: A Case Study from Indonesia, The Electronic Journal of e-Learning 18(4) (2020) 276-287. DOI: https://doi.org/10.34190/EJEL.20.18.4.001

[10] D.D. Prasetya, A.P. Wibawa, T. Hirashima, An Interactive Digital Book for Engineering Education Students, World Transactions on Engineering and Technology Education 16 (1) (2018) 54-59.

[11] G.J. Hwang, and C.L. Lai, Facilitating and Bridging Out-of-Class and in-Class Learning: An Interactive E-Book-Based Flipped Learning Approach for Math Courses, Journal of Educational Technology \& Society 20(1) (2017) 184-197.

[12] T. Soan, N.D. Herman, J. Maknun, E-books in teaching and learning process, in: Proceedings of the 5th UPI International Conference on Technical and Vocational Education and Training, vol. 299, Atlantis Press, Amsterdam, $2019 . \quad$ pp. 18-28. DOI: https://doi.org/10.2991/ictvet-18.2019.64

[13] J.L. Carvalho, R.L. Gonzalez, L.M.C. Garcia, J. C. Juarez, What is better to study: the printed book or the digital book?: an exploratory study of qualitative nature, in: in World Conference on Qualitative Research, vol. 1, Springer, Berlin, Heidelberg, 2014, pp. 34-45. DOI: https://doi.org/10.1007/978-3-030-01406-3 4

[14] A.G. Bus, Z.K. Takacs, C.A.T. Kegel, Affordances and Limitations of Electronic Storybooks for Young Children's Emergent Literacy, Developmental Review 35 (2015) 7997.

DOI: https://doi.org/10.1016/j.dr.2014.12.004

[15] L. Manley, R.P. Holley, History of The Ebook: The Changing Face of Books, Techical Services Quartely 29(4) (2012) 292-311.

[16] W. Widodo, E. Sudibyo, S. Suryanti, D.A.P. Sari, I. Inzanah, B. Setiawan, Multimedia in Improving Generation Z's Scientific Literacy, Indonesian Journal of Science Education 9 (2020) 248-256.

DOI: https://doi.org/10.15294/jpii.v9i2.23208 
[17] C. Butcher, C. Davies, M. Highton, Design Learning from Module Outline to Effective Teaching, 2006.

[18] A. Ghaebi, S. Fahimifar, E-book Acquisition Features: Attitude of Iranian Information Professionals, Journal of Electronic Library 29(6) (2011) 777-791. DOI: https://doi.org/10.1108/02640471111188006

[19] E.B. Johnson, CTL (Contextual Teaching and Learning), Corwin Press, 2014.

[20] A. Bozkurt, M. Bozkaya, Evaluation Criteria for Interactive E-Books for Open and Distance Learning, International Review of Research in Open and Distributed Learning 16(5) (2015) 5882.

[21] R. Fernando, A. Arnesih, Development of The Economic Life of The Community Old Village Tanjung Piayu Laut As A Culinary, Historia: Jurnal Program Studi Pendidikan Sejarah 3(2) (2018) 92-101.

[22] L.P. Onn, Reconciling Economic and Environmental Imperatives in Batam, ISEAS Publishing, 2018.

[23] D. Asmarazisa, T. Ratnawati, N. Rahmiwati, The Influence of Financial Capital, Human Capital, and Natural Resources Capital on Economic Growth and Its Impact on Community Welfare in the Industrial Area of Batam City of Riau Island Province, Saudi Journal of Economics and Finance 4(7) (2020) 308-314.

DOI: https://doi.org/10.36348/sjef.2020.v04i07.002

[24] U. Hernawan, N.Y. Geurhaneu, M. Zulfikar, Characteristic of Shallow Subsurface Quaternary Sediment in Nongsa Isle, Part of Putri Islands, Batam, based on Georadar Data Interpretation, Bulletin of the Marine Geology 34(2) (2019) 109-120. DOI: http://dx.doi.org/10.32693/bomg.34.2.2019.624

[25] P.M. Berns, G. Robert, Erickson, Contextual Teaching and Learning: Preparing Students for the New Economy, Eric, 2001.

[26] N. Ilhana, A. Yildirimb, S.S. Yilmazc, The Effect of Context-Based Chemical Equilibrium on Grade 11 Students' Learning, Motivation and Constructivist Learning Environment, International Journal of Environmental \& Science Education 11(9) (2016) 3117-3137. DOI: https://doi.org/10.12973/ijese.2016.919a
[27] M. Jauhari, PAIKEM Implementation. Prestasi Pustakaraya, 2011.

[28] A. Fadillah, N. Putu, L. Cintya, D. Ridho, A. Nurkholis, The effect of application of contextual teaching and learning (CTL) modelbased on lesson study with mind mapping media to assess student learning outcomes on chemistry on colloid systems, in: International Journal of Science and Apllied Science: Conference Series, vol 1, Universitas Sebelas Maret, Surakarta, 2018, pp. 101-108. DOI: https://doi.org/10.20961/ijsascs.v1i2.5128

[29] UNESCO, Education: From disruption to recovery, UNESCO, 2020. Accessed on: Oct, 2020. [Online]. Available: https://en.unesco.org/covid19/educationrespons $\underline{\mathrm{e}}$

[30] G.M. Johnson, The Influence of Student Learning Characteristics on Purchase of Paper Book and Ebook For University Study And Personal Interest, Educational Psychology 36(9) (2015) 1-16. DOI: https://doi.org/ $\underline{10.1080 / 01443410.2014 .1002831}$

[31] G.H. Huang, N. Korfiatis, Trying Before Buying: The Moderating Role of Online Reviews in Trial Attitude Formation Toward Mobile Applications, International Journal of Electronic Commerce 19(4) (2015) 97-111. DOI:

https://doi.org/10.1080/10864415.2015.1029359

[32] Parmin, Sajidan, Ashadi, Sutikno,Y. Maretta, Preparing Prospective Teachers in Integrating Science and Local Wisdom through Practicing Open Inquiry, Journal Turkish Science Education, 13(2) (2016) 3-14.

[33] I. Wilujeng, I.G.P. Suryadarma, W.S.B. Dwandaru, Local Potential Integrated Science Video to Improve SPS and Concept Mastery, International Journal of Instruction, 13(4) (2020) 12-22.

[34] E.C. Dewi, I.G.P. Suryadarma, I. Wilujeng, Using video integrated with local potentiality to improve student's concept mastery in natural science learning, in: AIP Conference Proceedings, vol. 1097, American Institute of Physics, Maryland, 2018, 1742-1752. DOI: https://doi.org/10.1088/1742$\underline{6596 / 1097 / 1 / 012001}$ 
[35] A.S. Ardan, The Development of Biology Teaching Material Based on the Local Wisdom of Timorese to Improve Students Knowledge and Attitude of Environment in Caring the Persevation of Environment, International Journal High Education 5(3) (2016) 190-200.

[36] I.D. Pursitasari, E. Suhardi, A.P. Putra, I. Rachman, Enhancement of student's Critical thinking skill through science context-based inquiry learning. Indonesian Journal of Science Education 9(1) (2020) 97-105. DOI: https://doi.org/10.15294/jpii.v9i1.21884 